\title{
Distribusi Vertikal Logam Pb, Zn, Cr dan Keterkaitannya Terhadap Karbon Organik Sedimen di Pantai Marunda, Jakarta
}

\author{
Triyanti Nurhidayah $^{1}$, Lilik Maslukah $^{1}{ }^{*}$, Sri Yulina Wulandari ${ }^{1}$, Kurnia $^{2}$ \\ ${ }^{1}$ Departemen Oseanografi, Fakultas Perikanan dan Ilmu Kelautan, Universitas Diponegoro \\ Jl. Prof. Soedarto, SH, Tembalang, Semarang, Jawa Tengah, 50275 \\ ${ }^{2}$ Pusat Survey Geologi, Bandung \\ Jl. Diponegoro No.57, Cihaur Geulis, Bandung, Jawa Barat 40122 \\ Email: lilik_masluka@yahoo.com
}

\begin{abstract}
Abstrak
Pantai Marunda terletak di Teluk Jakarta dan berdekatan dengan muara Sungai Tiram. Kegiatan antropogenik di sekitar Pantai Marunda sangat tinggi, sehingga dapat menyumbang limbah yang mengandung logam berat $\mathrm{Pb}, \mathrm{Zn}$ dan $\mathrm{Cr}$. Limbah logam berat yang terakumulasi dalam perairan, akan mengendap dalam sedimen dan seiring berjalannya waktu akan mengalami peningkatan. Tujuan dari penelitian ini, untuk mengetahui konsentrasi $\mathrm{Pb}, \mathrm{Zn}$, dan $\mathrm{Cr}$ berdasarkan kedalaman vertikal, hubungannya dengan karbon organik total (KOT) dan ukuran butir sedimen di Pantai Marunda. Sampel sedimen diambil menggunakan polietylen sediment core dan dipisahkan berdasarkan kedalamannya $(1-3 \mathrm{~cm}, 4-6 \mathrm{~cm}$, dan 7-9 $\mathrm{cm})$. Logam berat dalam sedimen dianalisis menggunakan metode destruksi asam dan diukur nilai absorbansinya menggunakan AAS, karbon organik total menggunakan metode loss of ignition (LOI) dan analisa tekstur sedimen dengan metode pengayakan dilanjutkan pemipetan. Hasil menunjukkan bahwa konsentrasi rerata logam berat $\mathrm{Pb}, \mathrm{Zn}, \mathrm{Cr}$ secara berurutan pada lapisan atas sebesar 5,14; 107,19; dan 12,79 ppm, lapisan tengah sebesar 4,41; 100,20; 12,28 ppm serta lapisan bawah sebesar 4,8; 101,30; 14,10 ppm. Logam berat $\mathrm{Zn}$ dan $\mathrm{Cr}$ berkorelasi positif kuat terhadap KOT dan persentase lumpur, sedangkan terhadap $\mathrm{Pb}$ berkorelasi negatif. Hasil penelitian ini menggambarkan bahwa distribusi logam berat $\mathrm{Pb}, \mathrm{Zn}$ dan $\mathrm{Cr}$ secara vertikal menunjukkan konsentrasi tinggi pada lapisan permukaan yaitu pada kedalaman sedimen 1-3 cm dan keberadaanya ditentukan oleh konsesntrasi KOT dan fraksi sedimen jenis lumpur.
\end{abstract}

Kata kunci: distribusi vertikal, trace metal $\mathrm{Pb}, \mathrm{Zn}, \mathrm{Cr}$

\section{Abstract \\ Vertical Distribution of Pb, Zn, Cr Metals and Their Relationship to Organic Carbon Sediment at Marunda Beach, Jakarta}

The Marunda Beach is located on the Jakarta Bay and adjacent to the mouth of the Tiram River. Anthropogenic activity around Marunda Beach is very high, so it can contribute the heavy metals such as $\mathrm{Pb}, \mathrm{Zn}$ and $\mathrm{Cr}$. The heavy metal will accumulate in the sediment and over time will be increase. The purpose of this study was to determine the vertical distribution of $\mathrm{Pb}, \mathrm{Zn}, \mathrm{Cr}$, and their relationship to total organic carbon (TOC) and the grain size. Sediment samples were taken using polyethylene cores and this sample separated based on their depth $(1-3 \mathrm{~cm}, 4-6 \mathrm{~cm}$, and 7-9 cm). The heavy metals were analyzed using acid destruction and absorbance values were measured using AAS, TOC using the loss of ignition (LOI) and sediment texture with a sifting method, followed by pipetting. The results showed that the average concentration of $\mathrm{Pb}, \mathrm{Zn}, \mathrm{Cr}$ in the upper layer was 5.14; 107.19; $12.79 \mathrm{ppm}$, in the middle layer of 4.41; 100.20; $12.28 \mathrm{ppm}$ and in the lower layer 4.8; 101.30; 14.10 ppm, respectively. $\mathrm{Zn}$ and $\mathrm{Cr}$ are strongly positively correlated to TOC and mud, and vice versa, the relationship to Pb is negative. The results of this study found that the vertical distribution of $\mathrm{Pb}, \mathrm{Zn}$ and $\mathrm{Cr}$ was high in the surface layer $(1-3 \mathrm{~cm})$ and their presence was determined by TOC concentration and mud fraction.

Keywords: vertical distribution, trace metal $\mathrm{Pb}, \mathrm{Zn}, \mathrm{Cr}$ 


\section{PENDAHULUAN}

Pantai Marunda terletak di wilayah Kecamatan Cilincing, Teluk Jakarta dan dikenal sebagai salah satu destinasi wisata, kawasan padat penduduk, dan kawasan industri. Menurut Simbolon (2016), di wilayah Pantai Marunda terdapat industri yang bergerak di bidang properti, logistik, dan pelabuhan yang diantaranya adalah Kawasan Berikat Nusantara (KBN), PT. Pelindo, PT. Indah Kait, dan pabrik minyak kelapa sawit. Syaifullah et al. (2018) menjelaskan bahwa beberapa limbah logam berat dari kegiatan industri mengandung senyawa logam berat seperti timbal $(\mathrm{Pb})$, seng $(\mathrm{Zn})$, dan kromium $(\mathrm{Cr})$.

Logam berat merupakan pencemar yang tidak dapat terurai, pada konsentrasi tertentu dapat merugikan organisme dan lingkungan, serta dapat mengancam kesehatan manusia apabila masuk ke dalam rantai makanan (Palar, 2012; Chen et al., 2016; Putri \& Purwiyanto, 2016). Selain dihasilkan dari proses alami, senyawa logam berat dapat dihasilkan dari berbagai kegiatan manusia dan apabila memasuki perairan, akan cenderung diadsorpsi oleh partikel tersuspensi dan terakumulasi dalam sedimen (Putri \& Purwiyanto, 2016; Maslukah et al., 2017).

Sedimen tersuspensi merupakan pembawa kontaminan utama polutan, termasuk di dalamnya logam berat (Kljakovic'-Gašpic' et al., 2008). Seiring dengan berjalannya waktu, sedimen suspensi ini akan mengendap ke dasar sedimen dan konsentrasinya dapat bertambah akibat adanya penambahan aktivitas antropogenik (Kargin et al., 2001). Menurut Lopez \& Lluch (2000), lapisan sedimen yang diambil menggunakan sediment core dapat digunakan untuk mempelajari sejarah pencemaran dari suatu ekosistem perairan. Sediment core juga berisi informasi tentang peristiwa yang terjadi pada waktu tertentu (Harikumar et al., 2012; Cho et al., 2015, Chen et al., 2016).

Logam berat dalam sedimen memiliki hubungan yang sangat kuat dengan keberadaan bahan organik (Liu et al., 2011; Fitroh et al., 2019). Logam berat yang terlarut dalam air akan berpindah ke dalam sedimen jika berikatan dengan materi organik bebas atau materi organik yang melapisi permukaan sedimen (Chakraborty et al., 2015; Fitroh et al., 2019) dan penyerapan langsung oleh permukaan partikel sedimen (Kinasih et al., 2015). Bahan organik dan logam berat akan lebih banyak terakumulasi pada sedimen fraksi halus (Simpson et al., 2013; Fitroh et al., 2019). Penelitian logam $\mathrm{Pb}$ dan $\mathrm{Zn}$ sebelumnya pernah dilakukan di teluk Jakarta oleh Kusuma et al. (2015) dan Fitroh et al. (2019) di Muara Sungai Tiram, yang merupakan bagian wilayah Marunda. Kedua penelitian yang dilakukan hanya mengkaji pola distribusi secara horisontal. Kajian pola distribusi secara vertikal di perairan ini belum pernah dilakukan. Berdasarkan latar belakang tersebut maka penelitian ini bertujuan untuk melihat distribusi konsentrasi $\mathrm{Pb}$, $\mathrm{Zn}$, dan $\mathrm{Cr}$ berdasarkan kedalaman vertikal dan keterkaitannya dengan karbon organik total (KOT) dan ukuran butir sedimen di Pantai Marunda.

\section{MATERI DAN METODE}

Penelitian ini dilaksanakan selama 3 bulan, yang terbagi menjadi 2 tahap yaitu : tahap pengambilan sampel di lapangan dan analisis sampel di laboratorium. Lokasi penelitian terletak di wilayah pantai Marunda, Jakarta Utara dengan letak lintang $106^{\circ} 57^{\prime} 51^{\prime \prime} \mathrm{BT}-106^{\circ} 57^{\prime} 34^{\prime \prime} \mathrm{BT}$ dan $6^{\circ} 05^{\prime} 33^{\prime \prime}$ LS - $6^{\circ} 05^{\prime} 38^{\prime \prime}$ LS (Gambar 1).

Sampel sedimen pada setiap stasiun diambil menggunakan alat polyetilen sediment core yang telah direndam dengan larutan $\mathrm{HNO}_{3}$ selama semalam dan dibilas dengan air suling bebas ion. Sampel yang diperoleh dipisahkan menjadi tiga bagian sesuai dengan kedalaman secara vertikal yaitu kedalaman 1-3 cm (lapisan atas), 4-6 cm (lapisan tengah), dan 7-9 cm (lapisan bawah) kemudian simpan ke dalam plastik dan dimasukkan ke dalam cool box untuk dibawa ke laboratorium untuk dianalisa konsentrasi Logam berat $(\mathrm{Pb}, \mathrm{Zn}$ dan $\mathrm{Cr})$, KOT dan ukuran butir sedimennya.

Analisis logam berat dan KOT dilakukan di Laboratorium Pusat Survey Geologi, Bandung dan analisis tekstur sedimen dilakukan di Laboratorium Geologi Laut, FPIK, Universitas Diponegoro. Metode analisa logam berat $\mathrm{Pb}, \mathrm{Zn}$ dan $\mathrm{Cr}$ dilakukan menggunakan metode desktruksi asam berdasarkan pada American Standard for Testing Material (ASTM) D 3974-81 (Moelyo et al., 2012). Sebanyak empat gram sampel sedimen kering yang telah bebas garam didekstruksi menggunakan larutan $\mathrm{HNO}_{3}$ pekat dan $\mathrm{HCl}$ pekat pada suhu $95{ }^{\circ} \mathrm{C}$, selanjutnya diukur nilai absorbansinya menggunakan AAS (VARIAN AA 280 FS). Untuk analisa Karbon Organik Total (KOT) sedimen menggunakan metode loss of ignition (LOI) (Meng et al., 2014). Analisa ukuran butir sedimen menggunakan metode dry sieving (pengayakan) dan wet sieving (pemipetan). Pada proses analisa ukuran butir sedimen, perhitungan fraksi lempung (clay) 
menjadi satu dengan lanau (silt), sehingga ukuran butir sedimen didapatkan dua fraksi yaitu pasir dan lumpur (lempung + lanau)

\section{HASIL DAN PEMBAHASAN}

\section{Konsentrasi Logam Berat dalam Sedimen}

Berdasarkan hasil penelitian menunjukkan bahwa konsentrasi rata-rata logam berat $(\mathrm{Pb}, \mathrm{Zn}$, $\mathrm{Cr})$ dari empat stasiun secara berurutan pada lapisan atas sebesar 5,14 ppm, 107,19 ppm dan $12,79 \mathrm{ppm}$, lapisan tengah sebesar 4,41 ppm, 100,20 ppm, 12,28 ppm dan pada lapisan bawah sebesar 4,8 ppm, 101,30 ppm, 14,10 ppm. Hasil lebih lengkap disajikan pada Tabel 1 dan pola distribusi logam berat $\mathrm{Pb}, \mathrm{Zn}$ dan $\mathrm{Cr}$ secara vertikal ditunjukkan pada Gambar 2.

Gambar 2 menunjukkan bahwa pola distribusi vertikal konsentrasi logam berat $\mathrm{Pb}, \mathrm{Zn}$ dan $\mathrm{Cr}$ memiliki pola yang tidak seragam. Hal ini diduga berkaitan dengan fluks masing-masing logam ke perairan bervariasi. Berdasarkan Tabel 1 dan Gambar 2, konsentrasi logam berat $(\mathrm{Pb}, \mathrm{Zn}$ dan $\mathrm{Cr}$ ) yang tertinggi secara umum terdapat pada lapisan atas, mengalami penurunan pada lapisan tengah dan kembali mengalami kenaikan pada lapisan bawah. Tingginya konsentrasi logam berat

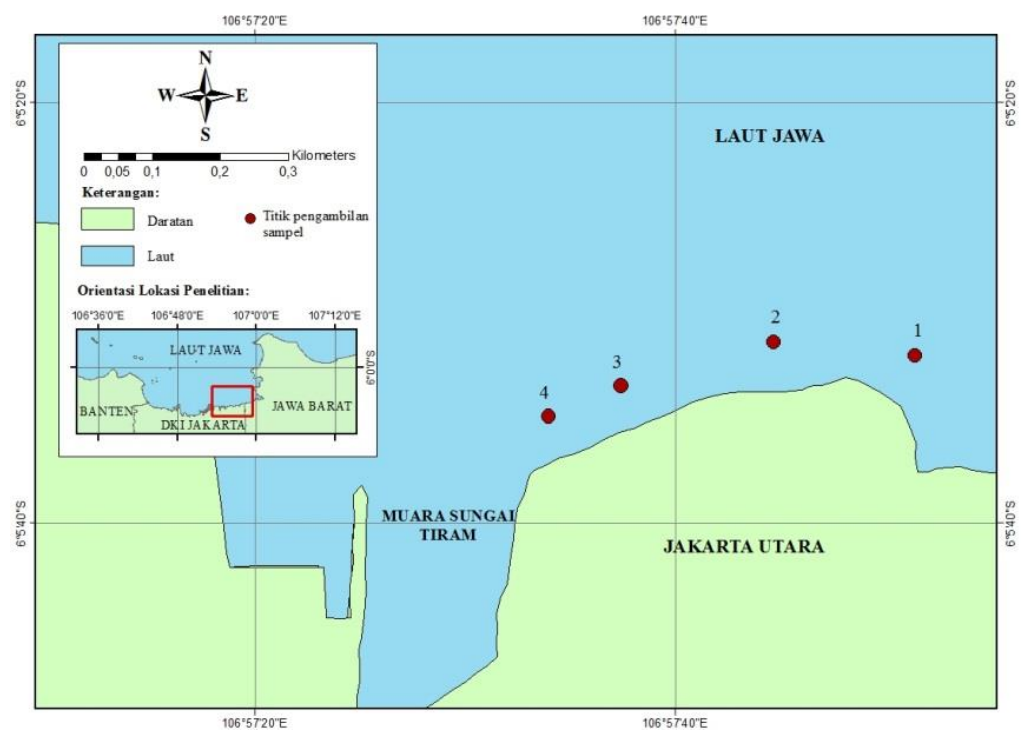

Gambar 1. Peta lokasi penelitian.

Tabel 1. Konsentrasi Logam Berat, KOT dan pH Sedimen Pantai Marunda

\begin{tabular}{|c|c|c|c|c|c|c|}
\hline \multirow{2}{*}{ Stasiun } & \multirow{2}{*}{$\begin{array}{c}\text { Kedalaman } \\
\text { Sedimen }(\mathrm{Cm})\end{array}$} & \multicolumn{3}{|c|}{ Logam Berat (ppm) } & \multirow{2}{*}{ KOT (\%) } & \multirow{2}{*}{$\mathrm{pH}$} \\
\hline & & $\mathrm{Pb}$ & $\mathrm{Zn}$ & $\mathrm{Cr}$ & & \\
\hline \multirow{4}{*}{1} & $1-3$ & 4,80 & 70,88 & 9,79 & 2,91 & 7,1 \\
\hline & $4-6$ & 4,20 & 76,50 & 10,90 & 3,14 & 6,6 \\
\hline & $7-9$ & 3,60 & 73,69 & 9,41 & 3,52 & 6,4 \\
\hline & Rerata & 4,20 & 73.69 & 10,03 & 3,19 & 6,7 \\
\hline \multirow{4}{*}{2} & $1-3$ & 8,50 & 120,38 & 13,9 & 4,47 & 6,9 \\
\hline & $4-6$ & 6,59 & 104,88 & 11,01 & 4,28 & 7,2 \\
\hline & $7-9$ & 7,21 & 96 & 12,56 & 4,98 & 7,1 \\
\hline & Rerata & 7,4 & 107,08 & 12,49 & 4,58 & 7,06 \\
\hline \multirow{4}{*}{3} & $1-3$ & 3,98 & 117,63 & 16,06 & 6,55 & 6,3 \\
\hline & $4-6$ & 3,75 & 110,75 & 15,68 & 5,53 & 6,9 \\
\hline & $7-9$ & 4,61 & 116,63 & 15,10 & 5,63 & 6,4 \\
\hline & Rerata & 4,1 & 115,00 & 15,61 & 5,90 & 6,5 \\
\hline \multirow{4}{*}{4} & $1-3$ & 3,31 & 119,88 & 13,5 & 6,12 & 7,1 \\
\hline & $4-6$ & 3,11 & 108,69 & 12,28 & 5,81 & 7,3 \\
\hline & $7-9$ & 3,94 & 118,88 & 14,10 & 4,83 & 7,2 \\
\hline & Rerata & 3,50 & 115,81 & 13,29 & 5,59 & 7,2 \\
\hline
\end{tabular}




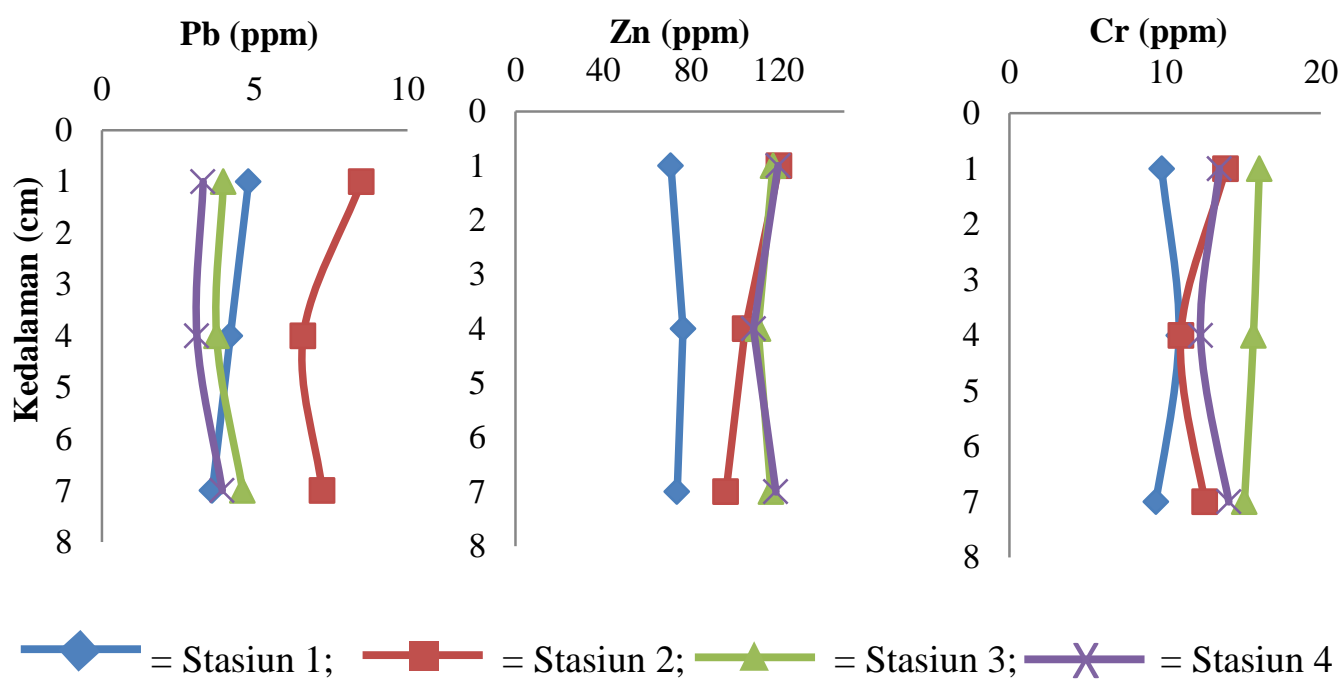

Gambar 2. Profil vertikal konsentrasi logam berat dalam sedimen

pada lapisan atas sedimen diduga disebabkan oleh meningkatnya masukan limbah ke perairan pantai akibat tingginya aktivitas antropogenik yang terdapat di wilayah Pantai Marunda pada saat ini. Cho et al., (2015) menyatakan bahwa lapisan sedimen dengan konsentrasi lebih tinggi menunjukkan tingginya kegiatan antropogenik pada waktu tersebut. Adanya variasi pada profil vertikal ini juga berkaitan dengan derajat keasaman $(\mathrm{pH})$ sedimen. Nilai $\mathrm{pH}$ sedimen menunjukkan kenaikan nilai pada lapisan tengah dan penurunan kembali pada lapisan bawah (Tabel 1). Palar (2012) menyatakan bahwa derajat keasaman $(\mathrm{pH})$ mempengaruhi kelarutan konsentrasi logam di kolom air. Kenaikan $\mathrm{pH}$ biasanya akan diikuti dengan semakin kecilnya kelarutan dari senyawa-senyawa logam, sehingga semakin besar yang mengendap di sedimen.

Konsentrasi tertinggi logam berat $\mathrm{Pb}, \mathrm{Zn}$ dan $\mathrm{Cr}$ terdapat pada stasiun yang berbeda-beda. Tabel 1 menunjukkan bahwa konsentrasi logam $\mathrm{Pb}$ yang tertinggi terdapat pada stasiun $2, \mathrm{Zn}$ tertinggi di stasiun 4 dan $\mathrm{Cr}$ pada stasiun 3 . Logam $\mathrm{Pb}$ lebih berkaitan dengan dengan letak stasiun 2 yang merupakan area lalu lintas kapal nelayan. Buangan air ballast dari kapal nelayan diduga menjadi sumber $\mathrm{Pb}$ pada sedimen. Sumber lain $\mathrm{Pb}$ adalah sisa pembakaran gas buang kendaraan motor dan cat (Walker et al., 1998). Selanjutnya, hasil penelitian Maslukah et al., (2019) menyatakan bahwa konsentrasi logam berat $\mathrm{Pb}$ ditemukan tinggi dalam sedimen pada stasiun dekat alur pelayaran nelayan. Hal ini berbeda dengan logam $\mathrm{Zn}$. Tingginya logam $\mathrm{Zn}$ distasiun 4 lebih disebabkan karena stasiun tersebut paling dekat kawasan industri dibandingkan dengan stasiun lainnya. Secara umum pola distribusi logam berat menurun seiring dengan bertambah jarak dari muara sungai (kecuali logam $\mathrm{Pb}$ ). Tinggi rendahnya konsentrasi logam berat disebabkan di antaranya oleh sumber logam berat tersebut dan berkaitan dengan kegiatan manusia (Mulyaningsih et al., 2012; Khan et al., 2017, Fitroh et al., 2019).

\section{Keterkaitan antara Logam Berat dan KOT pada Sedimen}

Analisis regresi linier digunakan untuk melihat model hubungan keterkaitan antara logam terhadap nilai KOT. Untuk melihat keeratan hubungan selanjutnya menggunakan nilai korelasi (r). Hasil analisis regresi linier disajikan pada Gambar 4.

Gambar 4 memperlihatkan bahwa KOT memiliki korelasi positif yang kuat dengan logam $\mathrm{Zn}$ dan $\mathrm{Cr}$ dengan masing-masing koefesien sebesar $r=0,817$ dan $r=0,829$. Pola yang sama juga ditemukan pada distribusi logam $\mathrm{Pb}$ secara horisontal di perairan Marunda, Teluk Jakarta (Fitroh et al., 2019). Hal ini disebabkan oleh logam berat yang terlarut dalam air akan berpindah ke dalam sedimen jika berikatan dengan materi organik bebas atau materi organik yang melapisi permukaan sedimen (Kinasih et al., 2015; Chakraborty et al., 2015). Pola hubungan antara KOT terhadap distribusi vertikal $\mathrm{Pb}$ penelitian ini berkebalikan dengan hasil $\mathrm{Zn}$ dan $\mathrm{Cr}$, dan hasil dari penelitian yang dilakukan oleh 
Fitroh et al. (2019). Konsentrasi logam $\mathrm{Pb}$ yang dianalisis pada penelitan fitroh et al. (2019) merupakan hasil analisis terhadap distribusi horisontalnya. Hasil ini sama dengan hasil penelitian Maslukah et al. (2019), yang tidak menemukan hubungan antara konsentrasi logam $\mathrm{Pb}$ dan KOT. Keberadaan $\mathrm{Pb}$ dalam sedimen dipengaruhi oleh faktor lain seperti komposisi mineral sedimen, kandungan hidroksida, karbonat, sulfida, dan enrichment factor (Kljakovic'Gas "pic' et al., 2008).

\section{Keterkaitan antara Logam Berat $(\mathrm{Pb}, \mathrm{Zn}, \mathrm{Cr})$ dan Ukuran Butir Sedimen}

Hasil analisis regresi linier $\mathrm{Pb}, \mathrm{Zn}$, dan $\mathrm{Cr}$ terhadap ukuran butir disajikan pada Gambar 5.
Gambar 5 menunjukkan bahwa sedimen pasir memiliki korelasi negatif dengan logam $\mathrm{Zn}(\mathrm{r}=$ $0,68)$ dan $\mathrm{Cr}(\mathrm{r}=0,72)$ dan berkorelasi lemah terhadap $\mathrm{Pb}(\mathrm{r}=0,40)$. Hal ini disebabkan pasir memiliki tekstur kasar. Logam akan lebih sulit terakumulasi pada sedimen bertekstur kasar dibandingkan dengan sedimen yang memiliki tekstur yang lebih halus (Fitroh, et al., 2019)Sedimen lumpur (lanau dan lempung) menunjukkan korelasi positif terhadap $\mathrm{Zn}(\mathrm{r}=$ 0,73) dan $\mathrm{Cr}(\mathrm{r}=0,82)$ dan berkorelasi lemah dengan logam $\mathrm{Pb}(\mathrm{r}=-0,42)$ (Gambar 6). Lumpur memiliki tekstur yang halus sehingga lebih mudah diakumulasi oleh logam dibandingkan sedimen pasir. Fitroh et al. (2019) menyatakan bahwa partikel sedimen yang halus memiliki luas

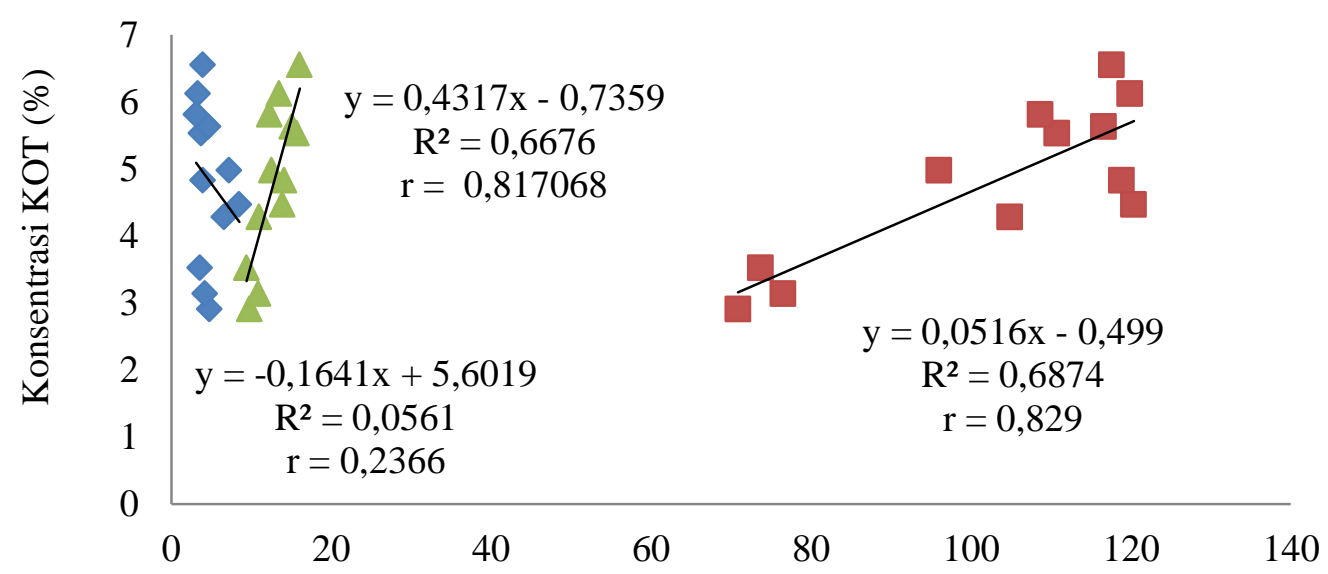

Konsentrasi Logam Berat (ppm)

$\diamond \mathrm{Pb} \quad \mathrm{Zn} \quad \Delta \mathrm{Cr}$

Gambar 4. Hubungan konsentrasi logam berat terhadap KOT dalam sedimen

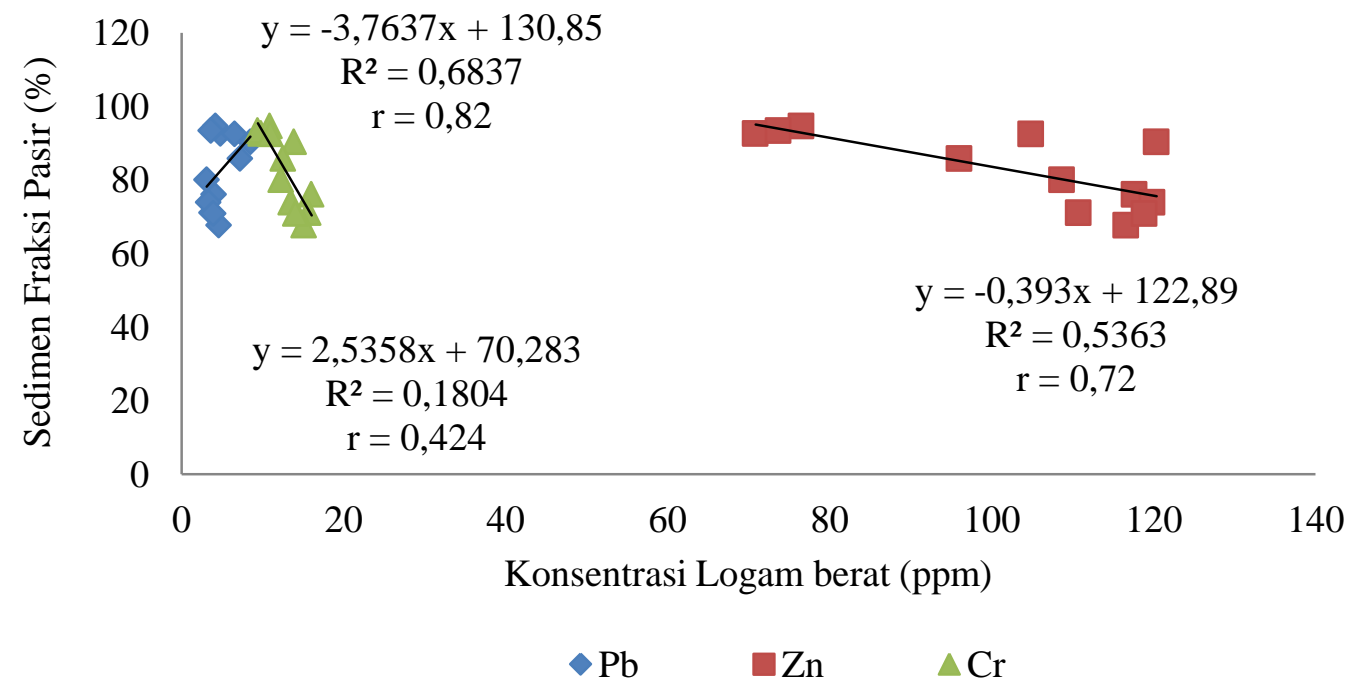

Gambar 5. Hubungan konsentrasi logam berat terhadap tekstur pasir 


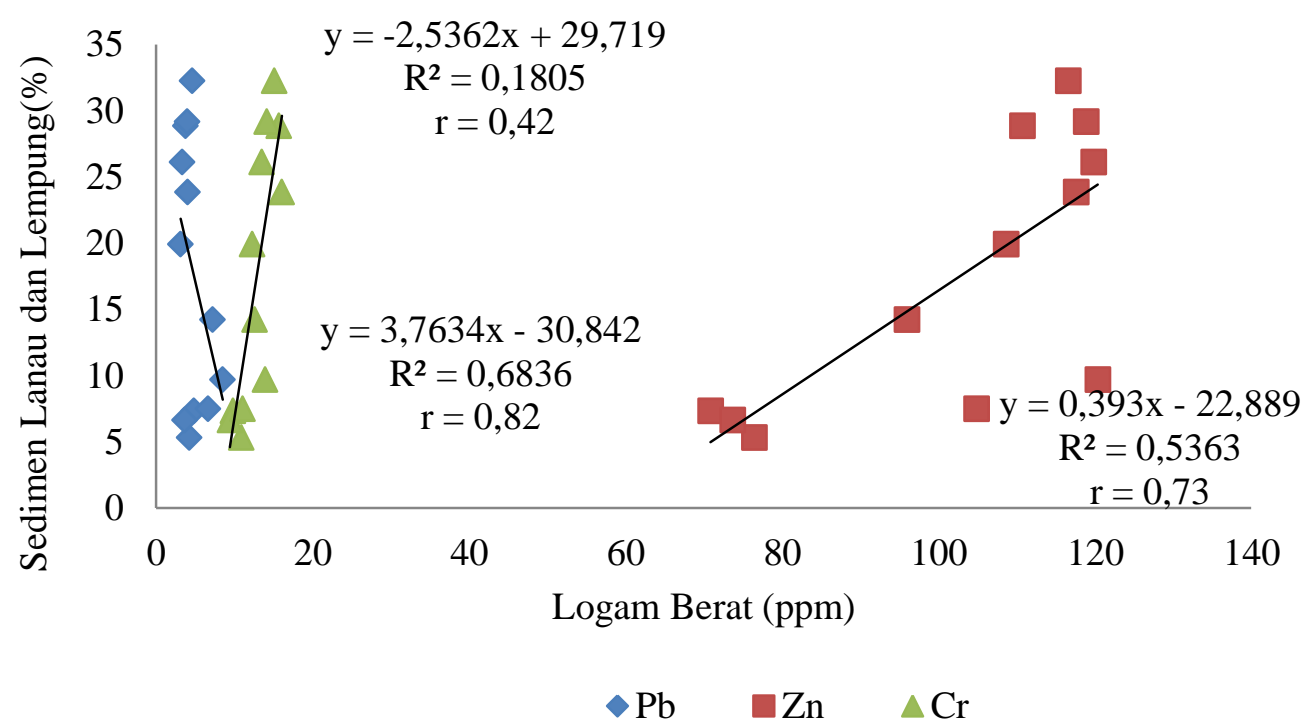

Gambar 6. Hubungan konsentrasi logam berat terhadap fraksi lumpur

Tabel 2. Konsentrasi logam berat pada sedimen pada daerah yang berbeda.

\begin{tabular}{|c|c|c|c|c|}
\hline Lokasi & $\mathrm{Pb}(\mathrm{mg} / \mathrm{kg})$ & $\mathrm{Cr}(\mathrm{mg} / \mathrm{kg})$ & $\mathrm{Zn}(\mathrm{mg} / \mathrm{kg})$ & Referensi \\
\hline Banjir Kanal Barat & $4,14-13,93$ & - & $94,11-183,39$ & Maslukah (2007) \\
\hline $\begin{array}{l}\text { Tuban, Gresik \& } \\
\text { Sampang }\end{array}$ & $2,90-3,36$ & $2,4 \cdot 10^{-5}-3,4 \cdot 10^{-}$ & $5,17-6,98$ & Syaifullah et al. (2018) \\
\hline Teluk Ambon & $51,3-163$ & 14.4 to 24.5 & $51,3-163$ & $\begin{array}{l}\text { Manullang et al. } \\
\text { (2017) }\end{array}$ \\
\hline $\begin{array}{l}\text { Wiso, Ujungbatu, Jepara } \\
\text { Teluk Jakarta }\end{array}$ & $33,57-79,63$ & $\begin{array}{l}- \\
-\end{array}$ & - & $\begin{array}{l}\text { Maslukah et al. (2019) } \\
\text { Kusuma et al. (2015) }\end{array}$ \\
\hline $\begin{array}{l}\text { Muara Sungai Tiram, } \\
\text { Marunda }\end{array}$ & $\begin{array}{l}24,86-59,32 \\
20,19-55,68\end{array}$ & - & $\begin{array}{l}26,14-241,01 \\
-\end{array}$ & Fitroh et al (2019) \\
\hline Marunda, Teluk Jakarta & $3,31-8,50$ & $9,41-16,06$ & $73,69-120,38$ & Penelitian ini \\
\hline
\end{tabular}

permukaan yang besar dengan kerapatan ion yang lebih stabil untuk mengikat logam daripada fraksi sedimen kasar. Sedimen dengan ukuran butir yang lebih kecil merupakan pembawa kontaminan utama, seperti bahan organik dan logam berat (Zhang et al., 2009; Kljakovic'-Gašpic' et al., 2008).

Hasil perbandingan dengan data penelitian konsentrasi $\mathrm{Pb}, \mathrm{Cr}$ dan $\mathrm{Zn}$ sedimen di lokasi lain, dapat dilihat pada Tabel 2. Konsentrasi logam $\mathrm{Pb}$, $\mathrm{Cr}$ dan $\mathrm{Zn}$ sedimen dasar di Pantai Marunda lebih kecil dibanding dengan Banjir Kanal Barat dan Teluk Ambon, namun menunjukkan nilai konsentrasi lebih tinggi dibanding Tuban, Gresik dan Sampang. Lokasi dan kedalaman pengambilan sedimen tentunya akan berpengaruh terhadap konsentrasi logam berat. Rendahnya konsentrasi logam dalam penelitian ini berkaitan dengan pengambilan sedimen yang hanya dilakukan pada perairan pantai dengan kedalaman kurang dari $1 \mathrm{~m}$. Pada kedalaman ini kondisi sedimen sangat dinamik oleh proses resuspensi akibat pengaruh arus dan gelombang.

\section{KESIMPULAN}

Berdasarkan hasil penelitian dapat disimpulkan bahwa distribusi logam berat di Pantai Marunda, Jakarta, pada lapisan atas cenderung lebih tinggi, diikuti lapisan bawah dan lapisan tengah. Konsentrasi rerata logam $\mathrm{Pb}, \mathrm{Zn}$, $\mathrm{Cr}$ dari empat stasiun secara berurutan pada lapisan atas sebesar 5,14 ppm, 107,19 ppm dan $12,79 \mathrm{ppm}$, pada lapisan tengah sebesar 4,41 ppm, $100,20 \mathrm{ppm}, 12,28 \mathrm{ppm}$ dan pada lapisan bawah sebesar 4,8 ppm, 101,30 ppm, 14,10 ppm. Pola fluktuatif konsentrasi menunjukkan adanya perbedaan inputan akibat kondisi perairan yang terjadi puluhan tahun yang lalu dan selama proses 
pengendapannya dipengaruhi oleh karbon organik dan tekstur sedimen. Hasil analisis korelasi menunjukkan bahwa logam berat $\mathrm{Zn}$ dan $\mathrm{Cr}$ memiliki korelasi positif terhadap KOT dan fraksi lumpur, dan sebaliknya logam berat $\mathrm{Pb}$ memiliki korelasi negatif.

\section{DAFTAR PUSTAKA}

Chakraborty, S., Chakraborty, P. \& Nath, B.N. 2015. Lead distribution in coastal and estuarine sediments around India. Marine Pollution Bulletin , 97: 36-46

Chen, C.F., Ju, Y.R., Chen, C.W. \& Dong, C.D. 2016. Vertical profile, contamination assessment, and source apportionment of heavy metals in sediment cores of Kaohsiung Harbor, Taiwan. Chemosphere, 165:67-79.

Cho, J., Hyun, S., Han, J.H., Kim, S. \& Shin, D.H. 2015. Historical trend in heavy metal pollution in core sediments from the Masan Bay, Korea. Marine Pollution Bulletin, 95:427-43.

Fitroh, I. S, Subardjo, P, dan Maslukah, L. 2019. Hubungan Logam Berat $\mathrm{Pb}$ terhadap Fraksi Sedimen dan Bahan Organik di Muara Sungai Tiram, Marunda, Jakarta Utara. Buletin Oseanografi Marina, 8(2):61-66

Harikumar, P.S \& Natsir, U.P. 2012. Ecotoxicological Impact Assessment of Heavy Metals in Core Sediments of a Tropical Estuary. Ecotoxicology and Environmental Safety, Elsevier, 73:17421747.

Kargin, F., Donmez, A., \& Cogun, H.Y. 2001. Distribution of heavy metals in different tissues of the shrimp Penaeus semiculatus and Metapenaeus monoceros from the Iskenderum Gulf, Turkey: Seasonal Variations. Bulletin of Environment Contamination and Toxicology, 66:102-109.

Khan, M.Z.H., Hasan, M.R., Khan, M., Aktar, S. \& Fatema, K. 2017. Distribution of Heavy Metals in Surface Sediments of the Bay of Bengal Cost. Journal of Toxicology, 1:1-7

Kinasih, A.R.N., Pudjiono, P.W. \& Ruswahyuni. 2015. Analisis Hubungan Tekstur Sedimen dengan Bahan Organik, Logam Berat $(\mathrm{Pb}$ Dan Cd) dan Makrozoobentos di Sungai Betahwalang, Demak. Diponegoro Journal of Maquares, 4(3):99-107.

Kljakovic'-Gašpic, Z., Bogner, D. \& Ujevic, I. 2009. Trace Metals $(\mathrm{Cd}, \mathrm{Pb}, \mathrm{Cu}, \mathrm{Zn}$ and $\mathrm{Ni})$ in Sediment of the Submarine Pit Dragon Ear (Soline Bay, Rogoznica, Croatia). Environmental geology, 58(4):751-760.
Liu, S., Shi, X., Liu, Y., Zhu, Z., Yang, G., Zhu, A. \& Gao, J. 2011. Concentration distribution and assessment of heavy metals in sediments of mud area from inner continental shelf of the East China Sea. Environmental Earth Sciences, 64(2):567-579

Lopez, P. \& Lluch, X., 2000. Sediment Geochemistry of A Meromictic Coastal Lagoon, Escibollar (Majorca, Spain). Limnetica, 18:15-27.

Manullang, C.Y., Lestari, L, Tapilatu, Y., Arifin, Z. 2017. Assessment of $\mathrm{Fe}, \mathrm{Cu}, \mathrm{Zn}, \mathrm{Pb}, \mathrm{Cd} \&$ $\mathrm{Hg}$ In Ambon Bay Surface Sediments. Marine Research Indonesia, 42(2):83-92. doi: https://doi.org/10.14203/mri.v42i2.170

Maslukah, L. 2007. Konsentrasi Logam Berat (Pb, $\mathrm{Cd}, \mathrm{Cu}, \mathrm{Zn})$ Terlarut, dalam Seston, dan dalam Sedimen di Estuari Banjir Kanal Barat, Semarang. Jurnal Aquatik, 2(1):1-4

Maslukah, L., Yudiati, E. \& Sarjito. 2017. Model Adsorpsi Logam Berat $\mathrm{Pb}, \mathrm{Cu}$, dan $\mathrm{Zn}$ Sistem Air-Sedimen Muara Sungai Banjir Kanal Barat Semarang. Maspari Journal, 9(2):149-158.

Maslukah, L, Wulandari, S.Y., Herlintang, A.S. \& Muslim. 2019. Konsentrasi Logam Berat Timbal $(\mathrm{Pb})$ dan Besi (Fe) Pada Sedimen Dasar Dan Keterkaitannya Dengan Karbon Organik Dan Ukuran Butir Di Perairan Wiso, Ujungbatu, Jepara. Maspari Journal, 10(2):149-158.

Meng, J., Yu, T.S., Bianchi, Paytan, A., Zhao, H. \& Yao, P. 2014. Distribution, mixing behavior, and transformation of dissolved inorganic phosphorus and suspended particulate phosphorus along a salinity gradient in the Changjiang Estuary. Marine Chemistry, 168:124-134

Moelyo, M., Tissa, J. \& Bambang, P. Pengaruh Kualitas Sedimen Dasar Terhadap Karakteristik Lingkungan Keairan, Studi Kasus; Saluran Tarum Barat. Jurnal Irigasi, 7(1):59-73.

Mulyaningsih, T.R., Alfian \& Sutisna. 2012. Distribusi Logam Berat dalam Sedimen Daerah Aliran Sungai Ciujung Banten. Jurnal Teknik Reaktor Nuklir, 14(3):157 169.

Palar, H. 2012. Pencemaran dan Toksikologi Logam Berat. Rineka Cipta, Jakarta.

Putri, W.A.E \& A.I. S. Purwiyanto.2016. Konsentrasi $\mathrm{Cu}$ dan $\mathrm{Pb}$ dalam Air dan Plankton di Sungai Musi Bagian Hilir. Jurnal Ilmu dan Teknologi Kelautan Tropis, 8(2):773-780. 
Syaifullah, M, Candra, Y.A., Soegianto, A. \& B. Irawan. 2018. Kandungan Logam Non Esensial $(\mathrm{Pb}, \mathrm{Cd} \mathrm{Dan} \mathrm{Hg})$ dan Logam Esensial (Cu, Cr Dan Zn) Pada Sedimen Di Perairan Tuban, Gresik Dan Sampang Jawa Timur. Jurnal Kelautan, 11(1):69-74

Simbolon, A. R., 2016. Status Pencemaran di Perairan Cilincing, Pesisir DKI Jakarta. Universitas Kristen Indonesia.

Simpson, S.L., Batley, G.E. \& Chariton, A.A. 2013. Revision of the ANZECC/ARMCANZ
Sediment Quality Guidelines. CSIRO Land and Water Science Report 08/07.

Walker, W.J., Mc Nut, R.P. \& Ann, C. 1998. The Potential Contribution of Urban Runoff to Surface Sediment of Passaic River Sources and Chemical Characteristics. Geomega, Chemical Land Holding Inc, 10(1):1-11.

Zhang, W., Feng, H., Qu, J. Xie, H. \& Yu, L., 2009. Heavy metal contamination in surface sediments of Yangtze River intertidal zone: An assessment from different indexes. Environmental Pollution, 157: 1533-1543. 